\title{
Determining the Rate of Salinity of Persian Gulf Waters with the Aid of Satellite Images and Least Squares Method
}

\author{
Ali Reza Moaddab', Mostafa Khabazi2 ${ }^{*}$, Hasan Roosta ${ }^{2}$ \\ ${ }^{1}$ Department of Surveying Engineering, Faculty of Engineering, Larestan Branch, Islamic Azad University, Larestan City, Iran \\ ${ }^{2}$ Department of Geography, Faculty of literature, Shahid Bahonar University of Kerman, Kerman, Iran \\ Email: *mostafakhabazi@uk.ac.ir
}

How to cite this paper: Moaddab, A.R., Khabazi, M. and Roosta, H. (2017) Determining the Rate of Salinity of Persian Gulf Waters with the Aid of Satellite Images and Least Squares Method. Open Journal of Marine Science, 7, 155-168.

http://dx.doi.org/10.4236/ojms.2017.71012

Received: October 6, 2016

Accepted: January 17, 2017

Published: January 20, 2017

Copyright $\odot 2017$ by authors and Scientific Research Publishing Inc. This work is licensed under the Creative Commons Attribution International License (CC BY 4.0).

http://creativecommons.org/licenses/by/4.0/

\section{c) (7) Open Access}

\begin{abstract}
As yet various methods have been used for determining the salinity rate of seas and oceans water. The current method of determining salinity rate of seas water has been field examination of various points of sea and determining its salinity rate. In the last decade, remote sensing satellite images have had high capability in determining sea waters salinity rate. Regarding that the present methods in remote sensing depend on the studied regions, therefore, the necessity of customization of these methods is felt. Fresh water springs due to impact on water salinity and temperature and also the environment physics and density like sound velocity are very significant and since coasts and islands of Persian Gulf are considered among arid and semi-arid regions and lack drinking water, access to fresh water springs has more significance. After studies performed, preparation of salinity rate observations and catching two series of proper images for felid data for complete coverage of the region, preprocessing and calibration was performed. For this purpose in turning the acquired radiance to reflection, ENVI software was used. The histogram of calibrated shades of gray rates in images was specified, so that reflection of each sample can be extracted from images. In this paper, the rate of least method efficiency in determining salinity rate of Persian Gulf waters was examined and finally identifying fresh water pits using remote sensing technique was done. The obtained results in the least squares methods after combining various bands of image with each other specified that combining 4 bands of 2, 3, 5 and 7 has the least standard deviation rate with training data and test, which is equal to 0.385 and 0.991978 .
\end{abstract}

\section{Keywords}

Salinity, Satellite Images, Least Squares Method, Landsat 5

\section{Introduction}

In continental respect, Iran is locates on the arid and semiarid world belt and its rain 
average is $250 \mathrm{~mm}$. according to the present statistics, $25 \%$ of Iran soil is located in extra dry regions, $40 \%$ in dry regions and $25 \%$ in semidry regions. Water sources are located in small part of the country area and should be transferred from these regions to two third of Iran area which is among shallow regions. Regarding the rate of water resources and consumption per capita, Iran is among countries which are in the group of countries faced with water shortage. This group includes countries which will face water physical shortage in 2025; this means that even with the highest possible efficiency in water consumption won't have enough water to supply their needs. About $25 \%$ of the world people including Iran are in this group.

Based on Falcon Mark indexes, National Organization index and International Institute of water management, Iran is in the threshold of standing in sever water crisis status. Based on mentioned indicators, for preserving its current status till 2025, Iran should be able to add $112 \%$ to its producible water resources that this rate regarding facilities and existing water resources seems impossible [1]. One of methods of increasing water resources in future is using present water resources in seas beds. Fresh water resources exist in some seas, so that the present underground aquifers present in lands could continue to seas and enter the sea as spring (Figure 1). Persian Gulf is not exempt from this case, Persian Gulf bed is the continuation of Zagros Mountain so that a part of its anticlines is visible as islands. In geology and petrology respect, Zagros Mountains are calcareous that this matter helps appearance and existence of springs in Persian Gulf, even some of these underground aquifers have been transferred towards Arabia and have appeared as sweet water springs [2]. Exit of underground aquifers

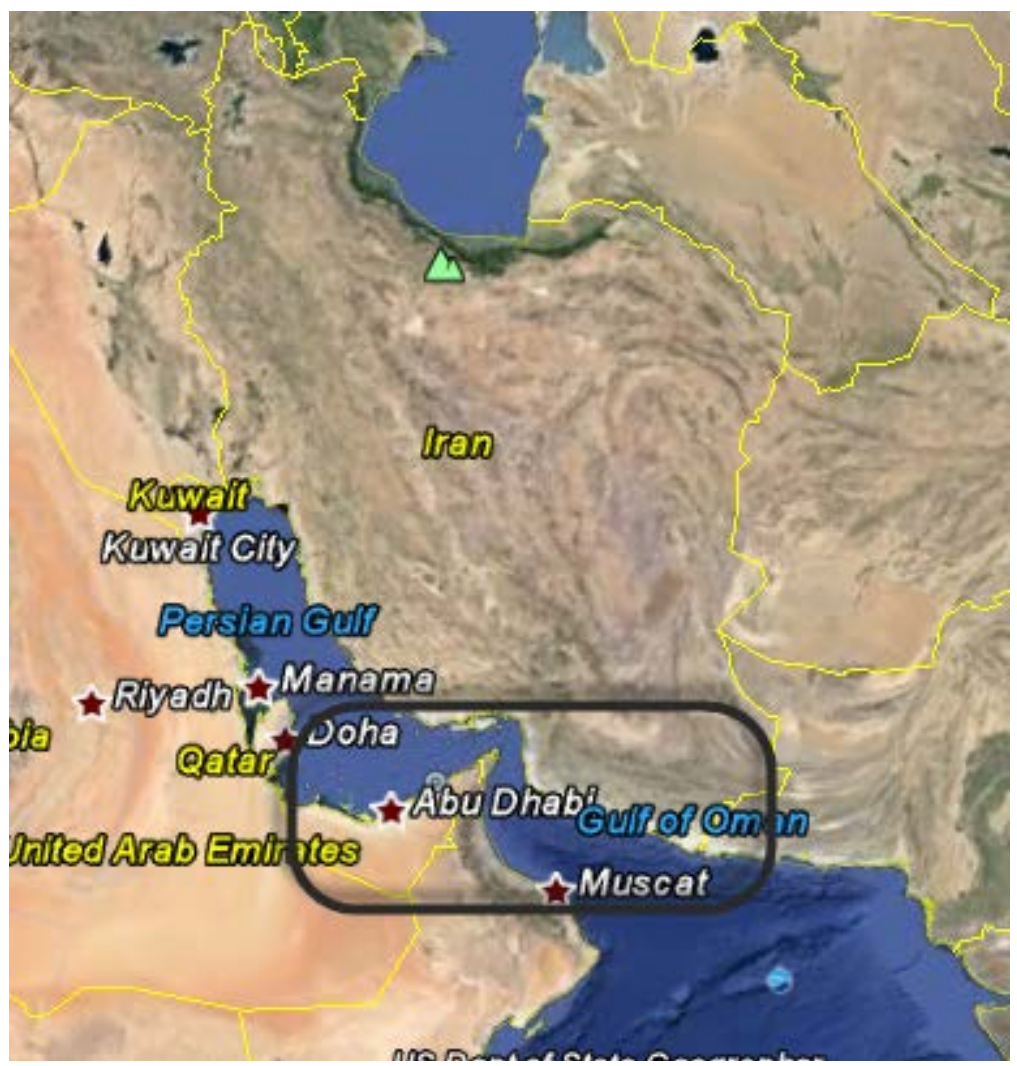

Figure 1. Geographical situation of studied range. 
(SDG) in some cases is featured as fresh water resources in sea bed and creates some changes in water salinity, temperature and density. Change in water density could impact marine streams, creating sonic channels and waves features that with the aid of these factors, these springs could be locating. Fresh water springs existent in seas and oceans is among new and intact resources of fresh water. One of places which have been considered in this respect is Persian Gulf. Locating of fresh water springs or regions which have less salinity, not only makes possible access to fresh water, but also will considerably help preventing environmental pollutions. Regarding that about $60 \%$ of all the world humidification are in Middle East, one of problems of these machines is that the most modern humidification has $50 \%$ efficiency, it means they convert half of water they take and the rest enters sea water as bittern. The rate of salts and heavy metals existent in bittern is about 64 to $70 \mathrm{ppt}$. portion in thousand. This means that due to activity of humidification machines daily more than 1 million and 200 thousands $\mathrm{m}^{2}$ bittern enters Persian Gulf. Persian Gulf due to its natural conditions doesn't have high speed of water full circulation, so for Persian Gulf water circulation to be able to have a full circulation and annihilate pollutions of Persian Gulf, 4 years' time is required. It is obvious that extracting fresh water springs or regions which have less salinity could help preventing from the sea environmental pollutions too [3] [4]. Also, desalination of waters which have less salinity will have less cost than saline waters, on this basis, one of the main objectives of this paper is to identify fresh water pits in saline environments with the aid of satellite images and remote sensing knowledge which besides having low cost comparing fresh water reactors is considerable in environment respect.

\subsection{The Research History}

Many studies have been performed bout identifying fresh water springs existent in seas abroad, but despite high significance of this issue, in arid and semiarid regions of Persian Gulf coasts and islands, this matter has less been noticed. Here, some studies performed in the field of appearance of fresh water springs in seas and their physical specifications are pointed (Table 1).

\subsection{Geographic Situation of Study Range}

Persian Gulf is located in 24 to 30 degrees and 30 minutes northern width and 48 to 56 degrees and 25 minutes eastern width from Prime Meridian. This Gulf intercommunicates with Oman Sea through Strait of Hormuz and through it to high Seas. The studied region is located in east of Persian Gulf (Strait of Hormuz) and part of Oman Sea in 25 degrees and 40 minutes to 27 degrees and 10 minutes of northern width and 56 degrees to 57 degrees and 17 minutes of eastern length from Prime Meridian. Due to existence of salinity data from this region, this part has been selected as studied region [5].

\section{Research Method}

In this article, for achieving research objectives, the following stages were performed and its flowchart is specified in Table 2 (Figure 2).

1) Library-documental examination by reviewing research literature, present articles and books. 
Table 1. Research literature about identifying fresh water springs existent in seas.

\begin{tabular}{|c|c|c|c|}
\hline Item & Scholar & Year & Result \\
\hline 1 & Khorram & 1982 & $\begin{array}{l}\text { This study's result shows correlation between sea water salinity rate and } \\
\text { Landsat TM assessing bands. }\end{array}$ \\
\hline 2 & Sonia et al. & 1982 & $\begin{array}{l}\text { They could use radar images ( microwaves) for determining seas water } \\
\text { salinity rate }\end{array}$ \\
\hline 3 & Laing & 1992 & $\begin{array}{l}\text { In US, for the first time, he could register locating fresh water using } \\
\text { electrical conduction in the form of an invention. In this method, a ship } \\
\text { moved parallel to coastal line and using an electrical Conductometer } \\
\text { which had been dropped out of the ship to the sea, identified } \\
\text { fresh water springs. }\end{array}$ \\
\hline 4 & Akawwi & 2006 & $\begin{array}{l}\text { In Jordan country, he could identify the exit spot of fresh water } \\
\text { springs using infrared imaging and field measuring of salinity } \\
\text { and temperature factors in Dead Sea. }\end{array}$ \\
\hline 5 & Ahn et al. & 2008 & $\begin{array}{l}\text { They showed that sea waters salinity rate is extractable using } \\
\text { satellite optic images. }\end{array}$ \\
\hline 6 & Palacios et al. & 2009 & $\begin{array}{l}\text { They used radar images for determining waters salinity rate. In radar } \\
\text { images, for determining sea waters salinity rate, measuring water } \\
\text { surface temperature rate is required. Therefore, they could make a } \\
\text { relation between sea waters salinity rate and surface temperature. }\end{array}$ \\
\hline 7 & Wong et al. & 2009 & $\begin{array}{l}\text { They found out that there is a linear relation between sea water salinity } \\
\text { and reflection rate of bands } 1 \text { to } 7 \text { of MODIS images. }\end{array}$ \\
\hline 8 & Marghani & 2010 & $\begin{array}{l}\text { They used MODIS images for determining water salinity rate } \\
\text { of Peninsular Malaysia. }\end{array}$ \\
\hline 9 & Urquhart & 2012 & $\begin{array}{l}\text { They used methods of Generalized Linear Model, Generalized additive } \\
\text { model, Artificial Neural Network, Multivariate Adaptive Regression } \\
\text { Spline, MODIS images, Geographic model and Tree based data mining } \\
\text { techniques and calculated each error rate. }\end{array}$ \\
\hline 10 & $\begin{array}{l}\text { Chen \& } \\
\text { Alabbadi }\end{array}$ & 2013 & $\begin{array}{l}\text { They used MODIS images and genetic algorithm for determining } \\
\text { Taiwan Strait waters salinity rate. In this method, it was hypothesized } \\
\text { that the previous research mathematics relation is not optimal and } \\
\text { just supports a linear state. For this reason, they used genetic } \\
\text { algorithm for determining the main relation between salinity } \\
\text { and MODIS image bands. }\end{array}$ \\
\hline
\end{tabular}

2) Preparing observations of Persian Gulf waters salinity rate which had been performed in field site by referring to respective organizations and receiving Ground Truth.

3) Preparing suitable images with Ground Truth data which uses Landsat 5 TM assessing images.

4) Preprocessing like radiometric and geometric corrections was performed on images.

5) Modeling among satellite data and measured information was performed in field site by Least Squares Method.

6) Examining methods accuracy by comparing estimated and real rates of some check spots. 
Table 2. A sample of data relating to salinity in studied range.

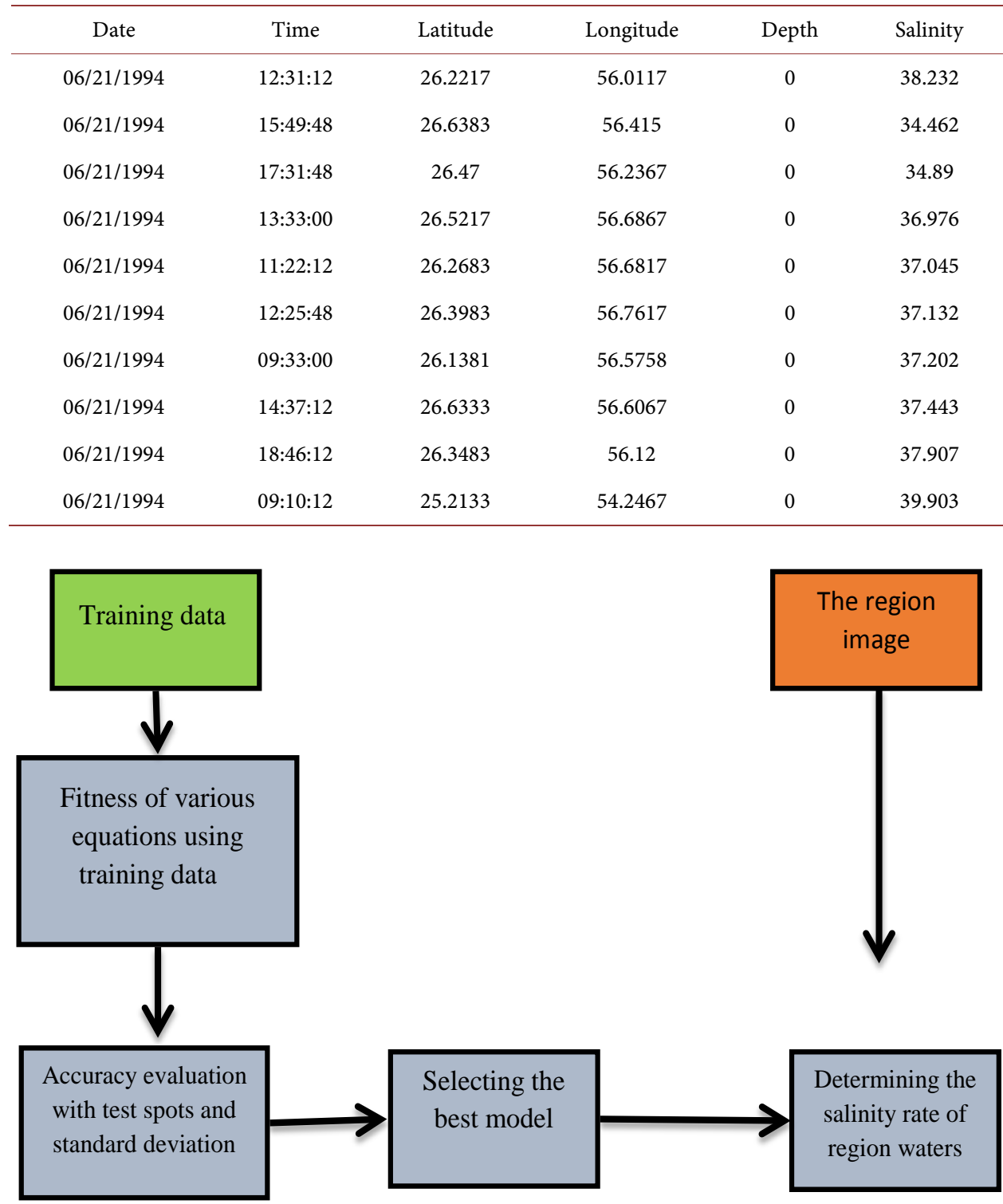

Figure 2. Various stages of study.

7) Preparing salinity map of studied region of Persian Gulf.

8) Identifying fresh water pits.

\section{The Research Findings}

For identifying salinity rate of the region waters, Landsat 5 TM assessor of 1994 was used [6].

But regarding that the studied region didn't stand in one imaging scene, 2 series of images were used for complete coverage of the region. Two taken images with close distance have been selected to minimize errors due to time change. Meanwhile, it should be pointed out that due to two parts of studied region being located in various courses of satellite, this issue was unpredictable. False colored display of images has been shown in Figure 3 and Figure 4. 


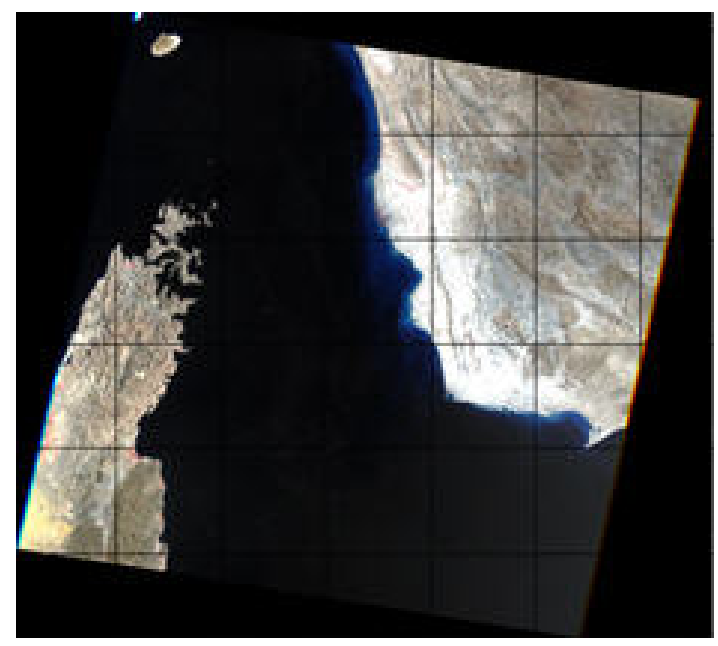

Figure 3. The true color from study zone in Landsat 5 TM images.

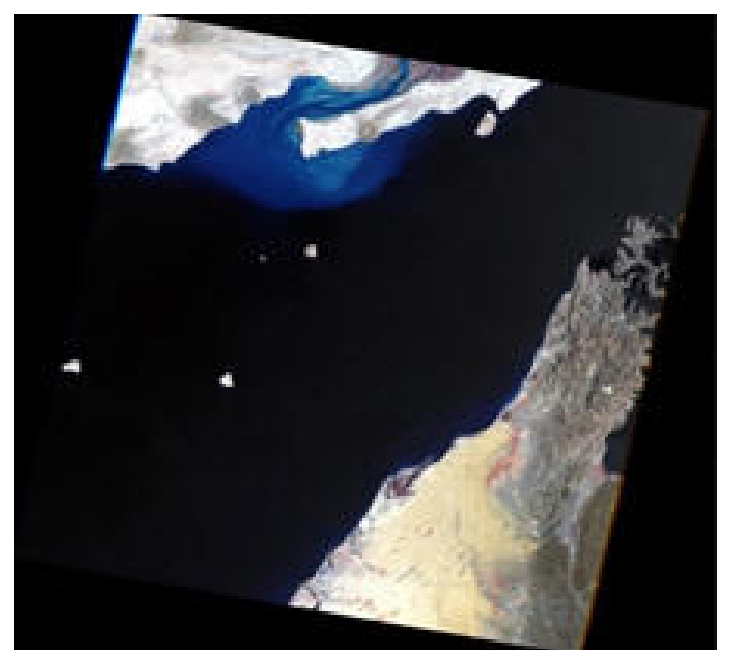

Figure 4. The false color from study zone in Landsat 5 TM images.

In the next stage, Landsat images were preprocessed and calibrated. After that, the rates of calibrated histogram shades of gray were obtained for images 3 and 4 (Figure 5 and Figure 6). For Figure 3, major shades of gray rates have been spread in the range of 0 to 0.3 . For Figure 4, major rates of shades of gray have been spread in the range of 0 to 0.25 .

\section{Salinity Data Taken from the Region}

For determining and modeling salinity rate of the studied region pixels requires having salinity rate sample in the region, so 55 samples of sea water surface salinity which had been removed by ship in the region was used [7]. for finding the best parameters from Least Squares, training data was required, also for evaluating fitness rate performed, it is required that with other spots accuracy rate to be examined, for this purpose, form 55 existent regions, 40 spots were used for training and 15 spots for evaluating the results.

This part of work aims to create a relation between TM assessor spectral bands (Bi) 

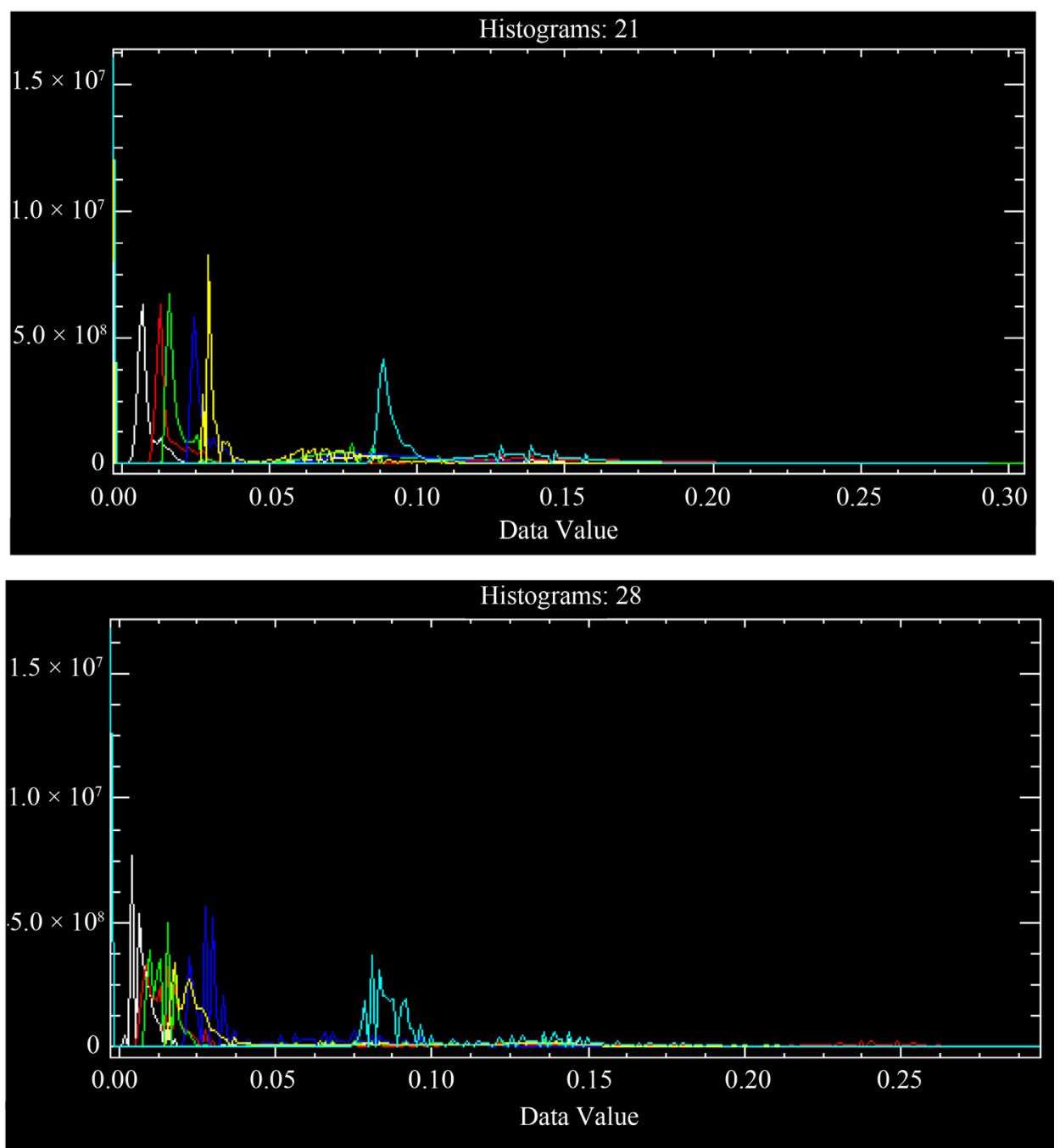

Figure 5. Histogram of salinity of Persian Gulf.

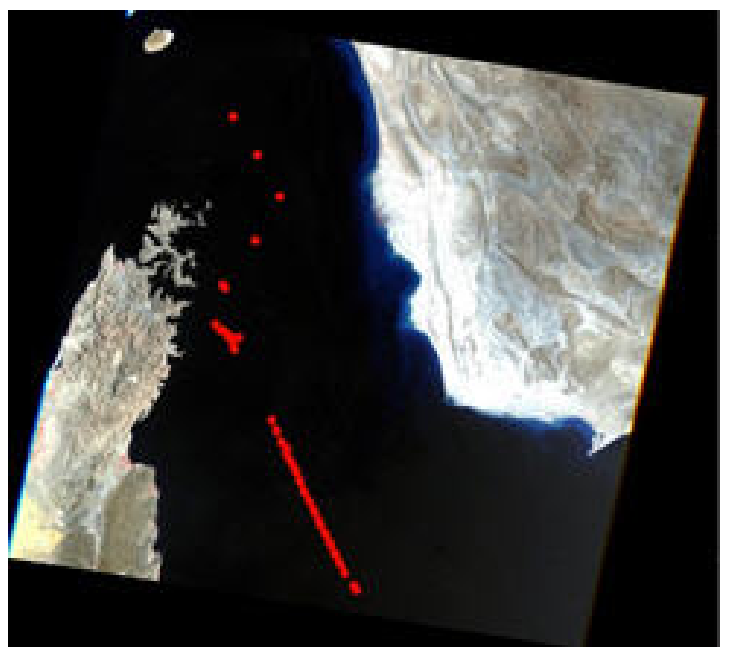

Figure 6. Ship survey course for catching data relating to salinity.

with salinity rate (S). For this purpose, 6 bands of Landsat images will be used. For this 
purpose, the general relation between bands and salinity rate will be the following relation:

$$
S=a_{0}+a_{1} * B 1+a_{2} * B 2+a_{3} * B 3+a_{4} * B 4+a_{5} * B 5+a_{6} * B 6 .
$$

The aim of Least Squares will be acquiring unknowns from $a_{0}$ to $a_{6}$ that unknowns will be obtained according to what was stated in previous part. For evaluating the results accuracy on training spots and testing the estimated rate of salinity and real rate is obtained and from standard deviation criterion, error rate criterion will be calculated according the following equation:

$$
S T D=\sqrt{\frac{\left(S_{i}-\widehat{S i}\right)^{2}}{N-1}} .
$$

Regarding that there are 6 spectral bands and this question is propounded that which band will have the best result. So in this article, various permutations of 2, 3, 4, 5 and 6 will be used for modeling salinity so that the best combination to be obtained with the least error and finally using that combination and the region image, salinity rate of various pixels is calculated.

\section{Binary Combinations}

Various binary combinations were used among images bands and the rate of error and unknown parameters for each was calculated [8]. In Table 3, the error rate of training spots has been displayed for various combinations. In Table 4, the error rate of test spots has been displayed for various combinations. As it is observed, the rate of standard deviation of training data is less than test data that this issue is due to that their fitness is natural. Based on test data, the best results have been obtained for combination of two bands of TM assessors 5 and 7 .

Table 3. Data fusion of Landsat 5 and Landsat 7.

\begin{tabular}{ccc}
\hline Band 1 & Band 2 & STD \\
\hline 1 & 2 & 0.391891 \\
1 & 3 & 0.38997 \\
1 & 4 & 0.387528 \\
1 & 5 & 0.390043 \\
1 & 6 & 0.383896 \\
2 & 3 & 0.396236 \\
2 & 4 & 0.393799 \\
2 & 5 & 0.39255 \\
2 & 6 & 0.389361 \\
3 & 4 & 0.400286 \\
3 & 5 & 0.399309 \\
3 & 6 & 0.390277 \\
4 & 5 & 0.399688 \\
4 & 6 & 0.390384 \\
5 & 6 & 0.38925 \\
\hline
\end{tabular}


Table 4. Data Fusion of Landsat 5 \& 7: Bands 1,2 \& 3.

\begin{tabular}{|c|c|c|c|}
\hline Band 1 & Band 2 & Band 3 & STD \\
\hline 1 & 2 & 3 & 1.006805 \\
\hline 1 & 2 & 4 & 1.033273 \\
\hline 1 & 2 & 5 & 1.003666 \\
\hline 1 & 2 & 6 & 0.997866 \\
\hline 1 & 3 & 4 & 1.023018 \\
\hline 1 & 3 & 5 & 1.005409 \\
\hline 1 & 3 & 6 & 0.995203 \\
\hline 1 & 4 & 5 & 1.022003 \\
\hline 1 & 4 & 6 & 1.009338 \\
\hline 1 & 5 & 6 & 0.991715 \\
\hline 2 & 3 & 4 & 1.026262 \\
\hline 2 & 3 & 5 & 1.006037 \\
\hline 2 & 3 & 6 & 0.998937 \\
\hline 2 & 4 & 5 & 1.029323 \\
\hline 2 & 4 & 6 & 1.009467 \\
\hline 2 & 5 & 6 & 0.991704 \\
\hline 3 & 4 & 5 & 1.020901 \\
\hline 3 & 4 & 6 & 1.012033 \\
\hline 3 & 5 & 6 & 1.002026 \\
\hline 4 & 5 & 6 & 1.003038 \\
\hline
\end{tabular}

\section{Triplex Combinations}

Various triplex combinations were used among the image bands and the error rate and unknown parameters were calculated for each. In Table 5, the error rate of training spots has been displayed for various combinations. In Table 4, the error rate of training spot has been displayed for various combinations. Based on test data, the best results have been obtained for combination of 3 bands of TM assessors 3, 5 and 7 .

\section{Quadric Combinations}

Various quadric combinations were used among image bands and the error rate and unknown parameters were calculated for each. In Table 6, the error rate of training spots has been displayed for various combinations. In Table 7, the error rate of test spots has been displayed for various combinations. Based on test data, the best results are for quadric combinations of TM assessors 2, 3, 5 and 7 bands.

\section{Quintuple Combinations}

Various quintuple combinations were used among image bands and the error rate and unknown parameters were calculated for each. In Table 8, the error rate of training spots has been displayed for various combinations. In Table 9, the error rate test spots 
Table 5. Quintuple Combinations of Landsat 5 \& 7: Bands 1 \& 2.

(a)

\begin{tabular}{ccc}
\hline Band 1 & Band 2 & STD \\
\hline 1 & 2 & 1.010132 \\
1 & 3 & 1.007302 \\
1 & 4 & 1.025952 \\
1 & 5 & 1.005238 \\
1 & 6 & 0.997578 \\
2 & 3 & 1.008524 \\
2 & 4 & 1.028673 \\
2 & 5 & 1.005834 \\
2 & 6 & 1.000075 \\
3 & 4 & 1.021685 \\
3 & 5 & 1.012673 \\
3 & 6 & 1.00544 \\
4 & 5 & 1.016623 \\
4 & 6 & 1.00761 \\
5 & 6 & 1.003723 \\
\hline & &
\end{tabular}

(b)

\begin{tabular}{|c|c|c|c|}
\hline Band 1 & Band 2 & Band 3 & STD \\
\hline 1 & 2 & 3 & 0.388659 \\
\hline 1 & 2 & 4 & 0.385084 \\
\hline 1 & 2 & 5 & 0.388271 \\
\hline 1 & 2 & 6 & 0.383865 \\
\hline 1 & 3 & 4 & 0.387265 \\
\hline 1 & 3 & 5 & 0.389437 \\
\hline 1 & 3 & 6 & 0.383168 \\
\hline 1 & 4 & 5 & 0.386787 \\
\hline 1 & 4 & 6 & 0.381115 \\
\hline 1 & 5 & 6 & 0.381789 \\
\hline 2 & 3 & 4 & 0.393503 \\
\hline 2 & 3 & 5 & 0.392397 \\
\hline 2 & 3 & 6 & 0.389282 \\
\hline 2 & 4 & 5 & 0.388573 \\
\hline 2 & 4 & 6 & 0.387922 \\
\hline 2 & 5 & 6 & 0.385488 \\
\hline 3 & 4 & 5 & 0.398799 \\
\hline 3 & 4 & 6 & 0.389884 \\
\hline 3 & 5 & 6 & 0.387609 \\
\hline 4 & 5 & 6 & 0.389246 \\
\hline
\end{tabular}


Table 6. Quintuple Combinations of Landsat 5 \& 7: Bands 1, 2, 3 \& 4.

\begin{tabular}{ccccc}
\hline Band 1 & Band 2 & Band 3 & Band 4 & STD \\
\hline 1 & 2 & 3 & 4 & 0.384032 \\
1 & 2 & 3 & 5 & 0.387075 \\
1 & 2 & 3 & 6 & 0.383075 \\
1 & 2 & 5 & 0.381744 \\
1 & 2 & 6 & 6 & 0.380449 \\
1 & 2 & 6 & 0.381261 \\
1 & 3 & 5 & 0.38678 \\
1 & 3 & 6 & 0.381098 \\
1 & 3 & 6 & 0.381788 \\
1 & 4 & 6 & 0.380065 \\
2 & 4 & 5 & 5 & 0.388409 \\
2 & 3 & 5 & 6 & 0.387917 \\
2 & 3 & 4 & 6 & 0.385282 \\
2 & 3 & 4 & 6 & 0.383837 \\
3 & 4 & 5 & 6 & 0.387177 \\
& 4 & 5 & &
\end{tabular}

Table 7. Continued from table 6. Quintuple Combinations of Landsat 5 \& 7: Bands 1, 2, 3 \& 4.

\begin{tabular}{ccccc}
\hline Band 1 & Band 2 & Band 3 & Band 4 & STD \\
\hline 1 & 2 & 3 & 4 & 1.029066 \\
1 & 2 & 3 & 5 & 1.003918 \\
1 & 2 & 3 & 6 & 0.994352 \\
1 & 2 & 5 & 5 & 1.031377 \\
1 & 2 & 6 & 1.012474 \\
1 & 2 & 6 & 0.989109 \\
1 & 3 & 5 & 1.021664 \\
1 & 5 & 6 & 1.008568 \\
1 & 3 & 4 & 6 & 0.991711 \\
1 & 3 & 4 & 6 & 1.003765 \\
2 & 4 & 5 & 5 & 1.031031 \\
2 & 3 & 5 & 6 & 1.009816 \\
2 & 3 & 4 & 6 & 0.991978 \\
2 & 3 & 4 & 6 & 1.005793 \\
3 & 4 & 5 & 6 & 1.009526 \\
\hline
\end{tabular}

have been displayed for various combinations. Based on test data, the best results has been obtained for quintuple combinations of TM assessors 1, 2, 3, 5 and 7. But, the obtained accuracy has been less than the best obtained accuracy for the best quadric combination, so the best bands which can determine salinity rate are: 2, 3, 5 and 7. Also, for 6 present spectral bands, the standard deviation rate of test and training data is equal 
Table 8. Continued from table 7. Quintuple Combinations of Landsat 5 \& 7: Bands 1, 2, 3 \& 4.

\begin{tabular}{cccccc}
\hline Band 1 & Band 2 & Band 3 & Band 4 & Band 5 & STD \\
\hline 1 & 2 & 3 & 4 & 5 & 0.381681 \\
1 & 2 & 3 & 4 & 6 & 0.380237 \\
1 & 2 & 3 & 5 & 6 & 0.381203 \\
1 & 2 & 4 & 5 & 6 & 0.37783 \\
1 & 3 & 4 & 5 & 6 & 0.37983 \\
2 & 3 & 4 & 5 & 6 & 0.382995 \\
\hline
\end{tabular}

Table 9. Quintuple Combinations of Landsat 5 \& 7: Bands 1, 2, 3, 4 \& 5.

\begin{tabular}{cccccc}
\hline Band 1 & Band 2 & Band 3 & Band 4 & Band 5 & STD \\
\hline 1 & 2 & 3 & 4 & 5 & 1.034214 \\
1 & 2 & 3 & 4 & 6 & 1.024383 \\
1 & 2 & 3 & 5 & 6 & 1.004073 \\
1 & 2 & 4 & 5 & 6 & 1.023723 \\
1 & 3 & 4 & 5 & 6 & 1.019703 \\
2 & 3 & 4 & 5 & 6 & 1.024426 \\
\hline
\end{tabular}

to: 1.009 and 0.3778 which is lower than the best result.

\section{Salinity Map}

For preparing salinity map, first the acquired equation between bands and salinity from Least Squares is according to the following relation:

$$
S=39.7975-36.7986 * B 2-16.4412 * B 3+90.9890 * B 5-55.6872 * B 7 .
$$

For identifying salinity rate of water regions, using ship file, mask region was created around these regions which is observed in Figure 7.

The obtained salinity map from Least Squares Methods has been displayed in Figure 8.

\section{Conclusion}

In this article, the main objective was to assess salinity rate of Persian Gulf water using satellite images and the Least Squares Method. So, regarding that there are 6 spectral bands in Landsat TM 5 images and that which band will have the best result, the best combination with least error has been calculated. The obtained results in the Least Squares method after combining the image various bands with each other, it was specified that the combination of 4 bands of 2, 3, 5 and 7 has the least standard deviation rate with test and training data, which is equal to 0.385 and 0.991978 . These rates show the difference between the estimated salinity and real salinity rate of samples. 


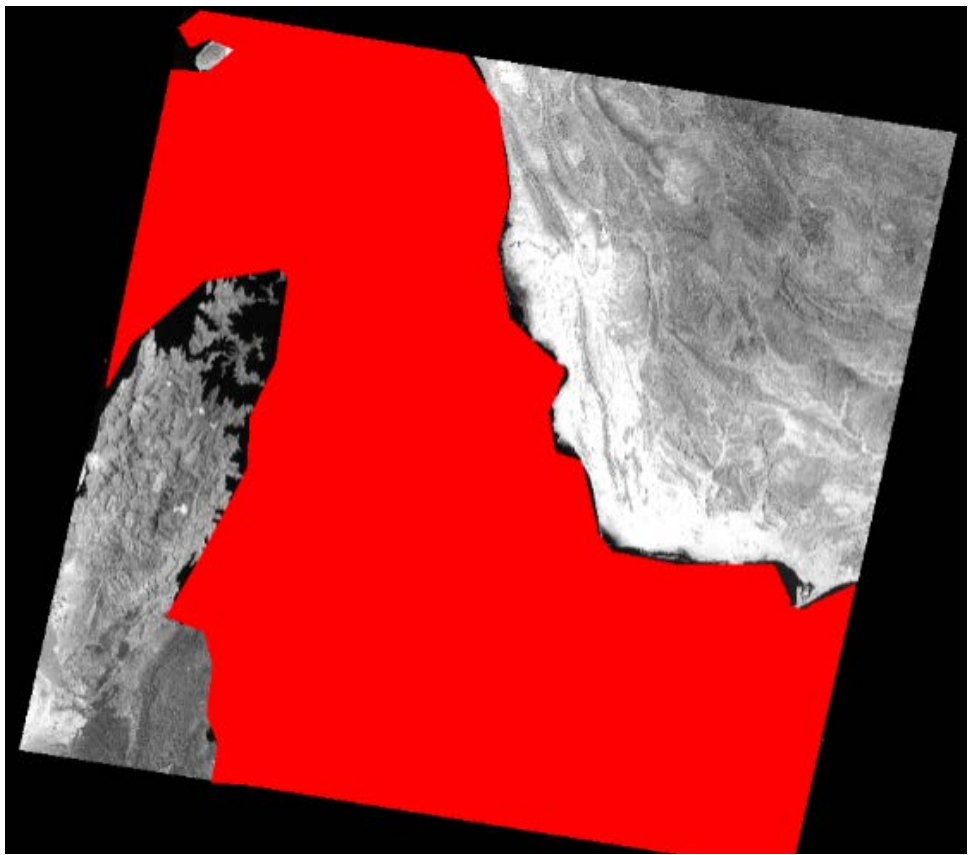

Figure 7. Creating mask around the studied region.

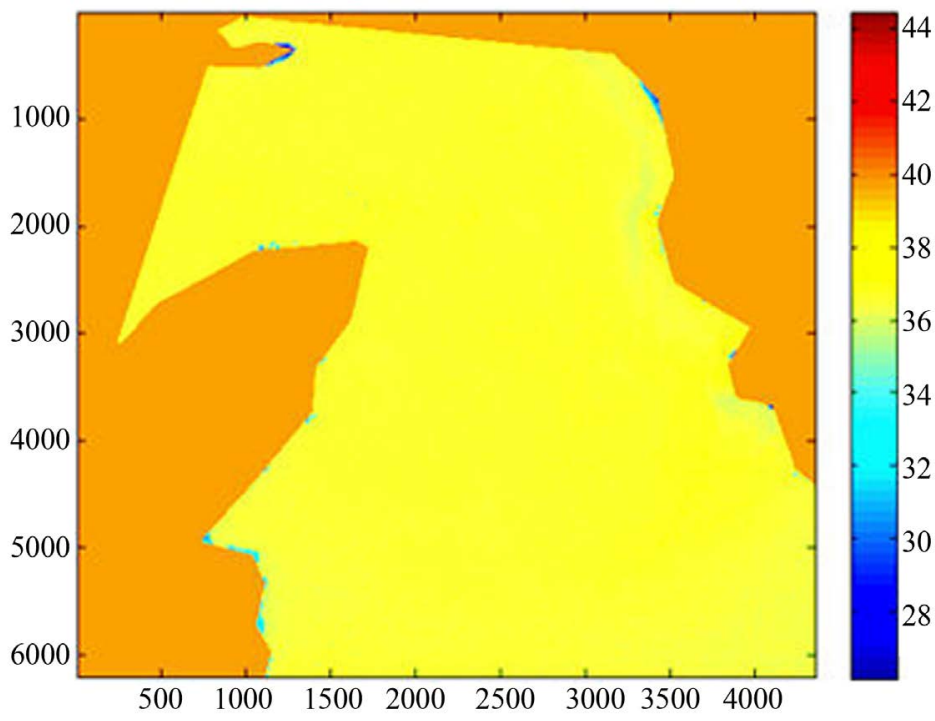

Figure 8. Salinity map of the studied range.

\section{References}

[1] Urquhart, E.A., Zaitchik, B.F., Hoffman, M.J., Guikema, S.D. and Geiger, E.F. (2012) Remotely Sensed Estimates of Surface Salinity in the Chesapeake Bay: A Statistical Approach. Remote Sensing of Environment, 123, 522-531. https://doi.org/10.1016/j.rse.2012.04.008

[2] Marghany, M., Hashim, M. and Cracknell, A.P. (2010) Modelling Sea Surface Salinity from MODIS Satellite Data. Computational Science and Its Applications-ICCSA 2010, Fukuoka, Japan, 23-26 March 2010, 545-556. https://doi.org/10.1007/978-3-642-12156-2_41

[3] Alabbadi, B.M.M. and Chen, L. (2013) Applying Genetic Algorithm Combining Operation Tree (GAOT) for Estimating Salinity of Taiwan Strait Using MODIS/Terra. 2013 Fourth Global Congress on Intelligent Systems (GCIS), Taiwa, 3-4 December 2013, 16-20. https://doi.org/10.1109/gcis.2013.8 
[4] Ahn, Y.-H., Shanmugam, P., Moon, J.-E. and Ryu, J.-H. (2008) Satellite Remote Sensing of a Low-Salinity Water Plume in the East China Sea. Annales Geophysicae, 26, 2019-2035. https://doi.org/10.5194/angeo-26-2019-2008

[5] Palacios, S.L., Peterson, T.D. and Kudela, R.M. (2009) Development of Synthetic Salinity from Remote Sensing for the Columbia River Plume. Journal of Geophysical Research: Oceans (1978-2012), 114, No. C2.

[6] Zine, S., Boutin, J., Waldteufel, P., Vergely, J.-L., Pellarin, T. and Lazure, P. (2007) Issues about Retrieving Sea Surface Salinity in Coastal Areas from SMOS Data. IEEE Transactions on Geoscience and Remote Sensing, 45, 2061-2072. https://doi.org/10.1109/TGRS.2007.894934

[7] Ellison, W., Balana, A., Delbos, G., Lamkaouchi, K., Eymard, L., Guillou, C. and Prigent, C. (1998) New Permittivity Measurements of Seawater. Radio Science, 33, 639-648. https://doi.org/10.1029/97RS02223

[8] Khorram, S. (1982) Remote Sensing of Salinity in the San Francisco Bay Delta. Remote Sensing of Environment, 12, 15-22.

Submit or recommend next manuscript to SCIRP and we will provide best service for you:

Accepting pre-submission inquiries through Email, Facebook, LinkedIn, Twitter, etc. A wide selection of journals (inclusive of 9 subjects, more than 200 journals) Providing 24-hour high-quality service User-friendly online submission system Fair and swift peer-review system Efficient typesetting and proofreading procedure Display of the result of downloads and visits, as well as the number of cited articles Maximum dissemination of your research work

Submit your manuscript at: http://papersubmission.scirp.org/

Or contact ojms@scirp.org 